\title{
The Investigation of ICT Needs in the Learning Process of Digital Natives
}

\author{
Jean Elikal Marna, Menik Kurnia Siwi, Oknaryana \\ Faculty of Economics, Universitas Negeri Padang \\ Email: Menikkurnia@gmail.com
}

\begin{abstract}
The study aims to investigate and analyze the needs of information and communications technology (ICT) in the learning process of digital-native students of the Faculty of Economics, Universitas Negeri Padang in Indonesia. The data were collected by using a structured questionnaire, and it was analyzed by employing the descriptive method. The results of this study indicated that the majority of students use technology in the learning process, such as smartphones and laptops all the time. In general, students prefer using WhatsApp and e-learning to support their learning activity. The adoption of technology is affected by the easiness to use and provides a piece of fast and comprehensive information. Therefore, they believe that the use of technology is relatively high within the learning process of the digital natives that technology integration in education is highly demanded.
\end{abstract}

Keywords: Digital Natives, Information and Communications Technology, Learning Process

\section{INTRODUCTION}

The development and use of technology in the learning process become a widelydebated issue among experts. The discourse occurs following the enhancement and migration of the learners from the digital immigrant to digital natives. Digital native is a term for the generations born in the 1990s or later who grow and develop simultaneously with the use of technology during their activities. Prensky names them a generation of digital natives, and Tapscott calls them the Net Generation (Kivunja, 2014). This generation is highly passionate about developing knowledge and ability through Information and Communication Technologies (ICT).

Indonesia has been in rapid development in the use of the internet within society's lives. A survey by the Association of Indonesian Internet Service Provider (APJII) released that over 132.7 millions of Indonesian of the total population amounted to 256.2 million people use the internet. Students in Indonesia are also active internet users in their daily activities. The Indonesian government has also responded to this change and the existence of this information age by formulating policies to increase access, efficiency, efficiency, and quality of education and management of education with the implementation of ICT.

Researches related to the use of technology in education prove that the use of technology as a tool is beneficial in teaching and learning activities in the classroom, and it is believed to improve the student learning outcomes effectively (Killion, 2016). Using ICT as the primary media upon organizing learning activities can increase the learning process; from training to the appearance, from the 
classroom to the flexible place and time, from paper to online or channel, from physical facilities to the network, and from cycle time to the real one (Rosenberg, 2001).

The internet has shifted the formal education into e-learning, which is electronic or internet-based learning activities. Besides, learning resources and teaching materials are also provided in various formats and contents that allow anyone to access anywhere. It is commonly known as the digital library. The underlying rationale is that ICT has full and precise information advantages, easily accessible in the learning process, academic administration, and financial administration as well as technical support to facilitate obtaining the information (Gyamfi \& Gyaase, 2017).

Learning is an interactive process between the students and the environment, resulting in a behavioral change into the better one. In doing so, many factors may affect one's behavior, both internal and external. The primary duty of teachers and lecturers is to control the environment and support students' behavior change and competence formation (Mulyasa, 2007). Therefore, it is necessary to create a conducive environment that challenges students' curiosity, by which the learning process can be effectively conducted. There are several challenges In creating an effective learning process, one of which is to change educators' mindset or lecturers that they can provide an easy learning process and raise the students' curiosity. It is expected that the learning process can be fun and student-oriented. Feelings of excitement, enthusiasm, confidence, and openness are the fundamental principles for students to grow and develop into a man adaptable to uncertainty and welcome various challenges in the era of globalization (Mulyasa, 2007).

Lancaster and Stillman (2002); Reilly (2012), have grouped people based on their year of birth into four generations: 1) the Baby Boomer Generations, who were born between 1946-1964; generation X who was born between 1965-1980; Generation Y born between 1981-1999; and Generation Z in the 2000s and later (Reilly, 2012). This generation's classification can be used as a reference for educators who teach students of generation $\mathrm{Y}$ and Z. Every generation possesses different characteristics, but the generation $\mathrm{Y}$ and $\mathrm{Z}$ still have some in common. According to Barcelon (2019), generation $\mathrm{Y}$ and $\mathrm{Z}$ grow in computerization and the internet network era.

In general, two generations of $\mathrm{Y}$ and $\mathrm{Z}$ in detail, possess the following properties. First, Tech Savvy, which meaning that Generation Y and Z are always accompanied and supported by technology such as computers, mobile phones, gaming, MP3 players, and the internet. They are digital natives who are familiar with e-mail, short messages, and computer. They can know the rapid development of technology. Second, social networking sites and short messages have typically been developing for generation $\mathrm{Y}$ and $\mathrm{Z}$ so that they can be categorized as less sensitive and anti-social. They were indifferent, although others know privacy through social media.

Besides, the mobile phone makes the information circulate very fast, so they are more creative to communicate. When both generations finally find a job, they will modify their working environment significantly following the style and their expectations; Multitasking, Generation Y, and Z are familiar with the technology. They can do many things at once with technology. They can write, read, watch, talk, 
and eat simultaneously. This generation is used to be pressing a button or automation in performing various jobs. The closeness of the information technology that the information related to them, that any information is seen and considered. The characters of generation $\mathrm{Z}$ or digital natives let the educators switch the learning process using technology. If they do not run, this generation will be tricky. Therefore, learning will be more interesting and useful if the educator is familiar with the technology.

Information technology covers everything related to the process, a tool to manipulate and manage information. Besides, it can help to process and transfer data from one device to another. Mastering ICT means understanding and using the tech tools in general, including computer (computer literacy) and information within (Information literate). UNESCO (2004) defines that ICT is a technology used to communicate, create, manage, and distribute information. In general, ICT refers to the computer, internet, telephone, television, radio, and other audio-visual equipment.

The internet is seen as the primary source of information and is evenly distributed around the world. The unlimited information provided on the internet can be used as learning resources. The teacher or lecturer can do a few things, such as selecting, collecting, and commenting on some materials available on the internet and turning them into complete teaching materials. To find the appropriate teaching materials, teachers and lecturers should also have the skills to access the internet and use the search engine. If they are unable to input the right keyword, it takes a long time to find the desired information. Many search engines are available on a laptop or mobile phone. Every search engine has the intelligence to find the document, picture, audio (sound), and video on the keywords or phrases inserted.

According to the Association for Educational Communication and Technology, learning resources are all the things that can be used by teachers or lecturers, in either partial or combination, to satisfy the teaching need to improve the effectiveness and efficiency of the learning process. Learning resources can be grouped into two parts: a) the source of the learning intentionally planned, which is specially developed as a component of the teaching system to provide the purposeful and formal facility of learning; b) the learning source used, which are the learning resources that are not explicitly designed for learning purposes. It can be searched, applied, and utilized for learning purposes, one of which is mass media. Mass Media is a type of communication aimed at an audience that is scattered, heterogeneous, and anonymous through print or electronic media. The message of the same information can be received simultaneously and quickly. The Media today can be in the form of mass media and mass media electronics; the internet also includes the media.

Through Rector's decree, No. 8 of 2018, Universitas Negeri Padang (UNP) has met the challenges of changing times. The rules that allow 50 percent of the lectures online require the students' readiness and lecturers; then, online lectures can be well done, especially in the Faculty of Economics. The use and application of ICT in support of learning in the classroom. It attempts to accommodate the needs of students who are digital natives in the sense that all activities conducted involving the internet in it. To support the process, UNP establishes an online learning system called e-learning UNP. However, even though e-learning has been made, ICT's use is 
perceived insufficient because it functions merely as a supporting tool for the learning process. Nevertheless, ICT use is supposed to be realized due to the learners' and lecturer's needs, not because of following the changes of times.

Teachers or lecturers need to know the students' readiness in performing ICTbased learning in terms of both intensity and ownership, so the process of learning can run optimally. Besides, they also need to be familiar with the exciting types of application and their benefit for the students' learning support.

\section{METHODS}

This research employed a descriptive survey analysis. The descriptive survey, according to Fraenkel, Wallen, and Hyung (2012), is a non-experimental design measuring the characteristics of the sample at a single time. The samples of the current research are ten percent of the total population. The population in this study was 2.716 respondents, while the sample was approximately 272 students from all departments in the Faculty of Economics, Universitas Negeri Padang. In more detail, it involved the Department of Economic Education, Economics, Management, Accounting, and a Master Degree Program.

The technique of sampling is required to determine the subjects of the research from every department. In this study, the sampling was calculated based on Riyanto (1996). In this way, the proportion of the samples from every department will be found. It used a Likert scale with four category options: (1) never, (2) Rarely, (3) sometimes, and (4) often. The researchers employed the descriptive analysis method through the following scale range formula:

$$
R s=\frac{\text { total sampling } x(\max \text { score }-\min \text { score })}{\text { interval }}
$$

The information about the research instruments is provided in table 1. In more detail, it cover several matters such as the intensity of technology use, the ownership and the use of technology and involves the students' opinion.

Table 1. Research Instruments

\begin{tabular}{cl}
\hline No. & \multicolumn{1}{c}{ Description } \\
\hline 1 & The Intensity of the Technology Use/Digital Applications \\
2 & The Ownership and Use of Electronic Devices \\
3 & The Use of Technology/Digital Applications in the Learning Process \\
4 & $\begin{array}{l}\text { The Opinion of Students on the Technology Use/The Applications Used in the } \\
\text { Learning Process } \\
5\end{array}$ \\
\hline
\end{tabular}

\section{RESULTS \& DISCUSSION}

\section{The Intensity of the Technology Use}

Kenedy (2010) categorizes the students using technology into four main types, primary user, irregular user, ordinary user, and power user (Kennedy, Judd, 
Dalgarnot, \& Waycott, 2010). The results of the study indicate that the technology use among students of the Faculty of Economics, Universitas Negeri Padang can be classified into several types: first, basic user, those who rarely use the new and updated technology, but they commonly use the standard features of mobile phone, phone call, and short message, with a total of 1.47 percent. Second, irregular users, those who use the standard website and mobile technology the minimum frequency with 8.46 percent. The next is that the ordinary user, students who use the standard website and mobile technologies with a monthly average of 22.06 percent. Lastly, power users, students who use a variety of technologies significantly, with 68.01 percent.

It indicates that most of the Faculty of Economics students, Universitas Negeri Padang, are significant users of technology (power user) amounting to 68 percent. Students use different types of technology, such as personal computers, laptops, and smartphones. Also, they do browsing and use learning media significantly. This type of user always brings digital media devices, especially mobile phones, wherever they go. The current study finds different results from the study which mentioned that only approximately 15 percent of the respondents are power users (Kennedy, Judd, Dalgarnot, \& Waycott, 2010) and the research of Corrin et al. (2010) with only about 23 percent of power users or advance users. The difference occurs due to the difference in the time of the study that the respondents are the generations born in the 2000s or generation Z. The results of this study indicate that the Faculty of Economics students, Universitas Negeri Padang, are familiar with technology in everyday life, and they are categorized as digital natives. Thus, the lectures will not find difficulty if the learning process is implemented using ICT.

\section{Ownership and the Use of Technology}

Table 2 summarizes the distribution of frequency analysis in terms of the ownership and the technology used by the students.

Table 2. The Ownership of the Devices/Technology

\begin{tabular}{|c|c|c|c|}
\hline Ownership & & Ownership & \\
\hline $\begin{array}{l}\text { Mobile Phone without } \\
\text { Internet Connection }\end{array}$ & $34.93 \%$ & Computer (PC) & $14.71 \%$ \\
\hline $\begin{array}{l}\text { Smartphone (with Internet } \\
\text { Connection) }\end{array}$ & $100 \%$ & $\begin{array}{l}\text { Portable Game } \\
\text { Console }\end{array}$ & $5.15 \%$ \\
\hline $\begin{array}{l}\text { Portable Media Player } \\
\text { Laptop/Notebook }\end{array}$ & $\begin{array}{l}5.51 \% \\
90.07 \%\end{array}$ & $\begin{array}{l}\text { Digital Camera } \\
\text { Game Console }\end{array}$ & $\begin{array}{l}13.97 \% \\
5.15 \%\end{array}$ \\
\hline
\end{tabular}

Source: Data processed (2019)

Table 2 shows that the students' ownership of smartphones is entirely high. All of the students in the Faculty of Economics, Universitas Negeri Padang own and use a smartphone. The ownership of the laptop/notebook is also high, amounting to 90.07 percent. It is then followed by ownership of mobile phones without internet with 14 percent 71 percent and the computer with approximately 14.71 percent. In line with the research of Margaryan et al. (2011), the fact that all of the respondents use smartphones shows that students have been familiar with the technology. However, technology is not necessarily used for finding information in the learning process. 
Besides the ownership of the devices/technology, the researchers also see the order of using the technology from the most often to least used by the students. Laptop ranks first in terms of usage, followed by smartphones, mobile phones, computers, digital cameras, and portable media players, while console games are rarely used.

\section{The Use of Technology in Teaching and Learning}

In terms of the technology used in learning, the researchers examine the frequent use of applications among students in the Faculty of Economics, Universitas Negeri Padang. Based on questionnaires distributed, Whatsapp, websites, and e-learning are the top three technologies used in the learning process (see Table 3).

Whatsapp is the most commonly used application, with approximately 69.9 percent of the Faculty of Economics students, Universitas Negeri Padang. WhatsApp can be used in the learning process, for either providing learning materials, submitting a task, and discussing the elements. It goes in line with Sartika (2018) research, which finds out that the lecture uses WhatsApp as a means to communicate for sending the handout of the course in case the students do not understand the material in the classroom. Besides, Whatsapp also functions as a means for submitting the task to the students for efficiency. The task can be quickly delivered and immediately received by the students.

Table 3. The Applications Used by Students in the Learning Process

\begin{tabular}{clc}
\hline No & Item & Percentage \\
\hline 1 & WhatsApp & $69.9 \%$ \\
2 & Website & $32.5 \%$ \\
3 & E-Learning & $18.5 \%$ \\
4 & E-mail & $10.1 \%$ \\
5 & Online Forum & $4.7 \%$ \\
6 & Twitter & $3.3 \%$ \\
7 & Blog & $2.5 \%$ \\
8 & Online Test/Quiz & $2.2 \%$ \\
9 & Facebook & $1.8 \%$ \\
\hline
\end{tabular}

Source: Data processed (2019)

E-learning has not been maximally used. About 18.5 percent of the students use e-learning in their learning process while Universitas Negeri Padang develops the leading media as a means of the online lecture. Following Rajiv et al. (2018) using the Technology Acceptance Model (TAM), the study shows that their Behavioral Intention to Use is high. However, e-learning is not maximally used in their learning activities.

\section{The Students Perspectives on the Application Prefered to Use for Learning and Entertainment}

The various application can be used in the learning process, but not all applications can maximally facilitate the students' learning process. This study also examines the preference of the students to an application for their learning process. It is expected that to be a reference for lecturers and policymakers in the faculty of Economics, Universitas Negeri Padang, to determine the proper application for online learning. 
Nine applications are provided in the questionnaire: e-learning, WhatsApp, websites, e-mail, online forums, online tests/quizzes, blogs, Facebook, and Twitter. Even if Whatsapp is most widely used, WhatsApp ranked in second place for the learning process. The majority of the Faculty of Economics students prefer elearning to be used in the process of learning because it contains all the necessary features. E-learning covers all the students' needs and lecturers to efficiently share the task and materials or conduct an online discussion. Rajiv et al. (2018) find external factors that affect the students' preference for e-learning, one of which is the lecturer who often shares the learning materials. The intensity of the lecturer's contribution to the use of e-learning needs to be improved that it can meet their expectation(Rajif, Slamet, \& Huda, 2018).

Technology is eventually used as a means of education or recreation by students. Thus, it is necessary to know the application preferred to use for learning and that for entertainment. The research on the nine applications provided in the questionnaire denotes that 66.3 percent of the students prefer WhatsApp, and about 26.4 percent of them prefer website for learning and entertainment. The number above shows that WhatsApp application is used for not only educational purposes but also entertainment. According to Prajana (2017), WhatsApp as an application for sending a short message or mobile messenger has managed to win the market. It is well accepted by society in general, including Indonesian teenagers (Prajana, 2017).

According to Sartika (2018), Whatsapp helps human life in terms of time, efficiency, and cost because of its practical use, such as sending a direct message through the internet from the smartphone. Users can also easily send pictures, videos, or even other files with high quality. Students do not need to open a laptop and e-mail to submit their tasks. They can send it through a smartphone and receive the lecturer (Sartika, 2018). The development of a learning application can refer to the features provided by WhatsApp, so it attracts the interest of students in using it for learning.

Facebook and Twitter occupy the third and fourth positions in the use of technology for recreational purposes. By using Facebook and Twitter, students can interact with their friends without space and time limitations. Besides, Facebook and Twitter present information that students like, such as the information related to the life of other people.

\section{The Opinion of Students about the Use of Technology in Learning}

Besides the students' ownership of the devices and the use of technology in learning, the researchers also examine their opinion on the use of technology in teaching and learning (see Table 4).

Table 4 indicates that the Faculty of Economics students, Universitas Negeri Padang, perceive technology as a positive device for the learning process. Through technology, they can learn new things, experience easy learning. Besides, finding materials online is also more manageable compared to searching for the printed one. However, there are a small number of students who do not feel comfortable using technology; even some of them consider it a burden and a waste of time. 
Table 4. The Opinion of Students on the Use of Technology in Teaching and Learning

\begin{tabular}{|c|c|c|c|c|c|}
\hline No. & Item & $\begin{array}{c}\text { Strongly } \\
\text { Agree }\end{array}$ & Agree & Disagree & $\begin{array}{l}\text { Strongly } \\
\text { Disagree }\end{array}$ \\
\hline 1 & $\begin{array}{l}\text { Through digital technology I can learn } \\
\text { new things }\end{array}$ & $74.2 \%$ & $25.1 \%$ & $0.7 \%$ & $0.0 \%$ \\
\hline 2 & Technology makes learning easier & $64.8 \%$ & $34.9 \%$ & $0.4 \%$ & $0.0 \%$ \\
\hline 3 & $\begin{array}{l}\text { It is easier to find the learning materials } \\
\text { online compared to the printed ones. }\end{array}$ & $48.5 \%$ & $47.1 \%$ & $3.6 \%$ & $0.7 \%$ \\
\hline 4 & $\begin{array}{l}\text { I do not feel comfortable using digital } \\
\text { technology in the learning process }\end{array}$ & $1.8 \%$ & $8.4 \%$ & $63.8 \%$ & $26.0 \%$ \\
\hline 5 & $\begin{array}{l}\text { The use of digital technology in the } \\
\text { learning process is a burden for me }\end{array}$ & $1.4 \%$ & $5.1 \%$ & $57.6 \%$ & $35.8 \%$ \\
\hline 6 & $\begin{array}{l}\text { Using digital technology in the learning } \\
\text { process only wastes energy and time. }\end{array}$ & $2.5 \%$ & $4.7 \%$ & $54.1 \%$ & $38.7 \%$ \\
\hline 7 & $\begin{array}{l}\text { My lecturer is not competent in using } \\
\text { technology }\end{array}$ & $1.5 \%$ & $8.7 \%$ & $62.4 \%$ & $27.5 \%$ \\
\hline
\end{tabular}

Source: Data processed (2019)

It concludes that not all generation $\mathrm{Z}$ are familiar with the technology. It is in line with Le et al. (2013), finding some students who are not comfortable using digital equipment. It happens because the respondents come from different areas, some of which, especially Western Tera, are still untouched by technological developments due to the less-evenly distributed development, education, and limited access to technology. According to them, there are still a few lecturers who are incompetent in using technology because some are not literate on technology. Students are familiar with the technology in the old age that they still reluctant to use technology.

\section{CONCLUSION}

The findings of the current study conclude that the Faculty of Economics students, Universitas Negeri Padang, include into power users, who always bring technological devices with them, exceptionally smartphone, wherever they go. However, technology is predominantly used for entertainment rather than learning. In the learning process, students often use various applications, such as WhatsApp, websites, and e-learning. Meanwhile, some students feel that using technology for learning is burdening. Therefore, it is necessary to develop the students' interest in using technology for learning, such as browsing the learning materials and using the tools that are friendly and accessible to all students. This study only discusses the use of various types of technology in the learning process, yet not all of the applications necessarily facilitate the learning objectives or increase the students' cognitive skills. Thus, the next researchers are suggested to examine the change in the cognitive skill of the students due to technological use. 


\section{REFERENCES}

Barcelon, B. (2019). The life of generation Z. Retrieved from http://teenlife.blogs.pressdemocrat.com/10220/the-life-of-generation-z/

Corrin, L., Lockyer, L., \& Bennett, S. (2010). Technological diversity: an investigation of students' technology use in everyday life and academic study. Learning, Media and Technology, 35(4), 387 - 401.

Gyamfi, S. A., \& Gyaase, P. O. (2017). Virtualization of university education: The impact of ICT-mediated learning environment on students' performance. International Journal of E-Services and Mobile Applications (IJESMA), 9(4), 24-40.

Fraenkel, J. R., Wallen, N. E., \& Hyun, H. H. (2012). How to design and evaluate research In educatIon (8th ed.). New York : Mc Graw HIll.

Kennedy, G., Judd, T., Dalgarnot, B., \& Waycott, J. (2010. Beyond natives and immigrants: exploring types of net generations students. Journal of Computer Assisted Learning, 26(5), 332-343.

Killion, J. (2016). When teachers learn to use technology, students benefit. The Learning Professional, 37(4), 64-75.

Kivunja, C. (2014). Theoretical perspectives of how digital natives learn. International Journal of Higher Education, 3(1), 94-109.

Lancaster, L., \& Stillman, D. (2002). When generations collide at work: managing traditionalists, baby boomers, generation Xers, and millennials. HarperCollins.

Lee, K. W., Thang, S. M., Tanc, C. K., Ng, S. I., Yoon, S. J., Chua, Y. W., \& Shirlenna, N. S. (2014). Investigating the ICT Needs of 'Digital Natives' in the Learning of English in a Public University in East Malaysia. Procedia - Social and Behavioral Sciences, 118, 242-250.

Margaryan, A., Littlejohn, A., \& Vojt, G. (2011). Are digital natives a myth or reality? University students' use of digital technologies. Computers \& Education, 56(2), 429-440.

Mulyasa, E. (2007). Standar kompetensi dan sertifikasi guru. Bandung: PT. Remaja Rosdakarya.

Prajana, A. (2017). Pemanfaatan aplikasi whatsapp dalam media pembelajaran di UIN Ar-Raniry Banda Aceh. Jurnal Pendidikan Teknologi Informasi, 1(2), 122133.

Rajif, J., Slamet, L., \& Huda, Y. (2018). Analisis penerimaan implementasi sistem informasi e-learning universitas negeri padang menggunakan pendekatan technology acceptance model. Voteknika, 53-63.

Reilly, P. (2012). Understanding and teaching generation Y. English Teaching Forum, $50(1), 2-11$.

Riyanto, Y. (1996). Metodologi Penelitian Suatu Tindakan Dasar. Surabaya: Sie Surabaya.

Rosenberg, M. J. (2001). E-Learning: Strategies for delivering knowledge in the digital age. USA: McGraw-Hill Companies.

Sartika. (2018). Kegunaan whatapps sebagai media iinformasi dan media pembelajaran pada mahasiswa ilmu komunikasi STISIP persada bunda. Medium Jurnal Ilmiah, 6(2), 15-26. 